content of those journals. Some journals have very little visibility, but those who communicate their research findings within the pages of those journals may be perfectly content with what they find therein. The rankings that I report here tap into a different evaluative dimension for political science journals. Journal impact, I would suggest, is a function of both the evaluations of a journal by those familiar with it, but also of the visibility of the journal to a wide range of political scientists. Having a lower general impact does not mean that a journal is not highly regarded by political scientists writing and reading in specific subfields to which the journal is directed, but only that the combination of evaluation and profession-wide visibility is lower than for other, more highly ranked journals.

The use of these two sets of rankings will depend upon the values that one brings to the evaluation process. Some political scientists, administrators, or departments will be interested in making assessments based on how journals are perceived by the (sometimes narrow) audiences with exposure to the journal. For instance, in hiring, promotion, and tenure decisions some faculty and administrators may be concerned with whether a candidate is publishing in journals that are highly regarded by the experts in a specific field, regardless of profession-wide visibility; in such a case, a publication in China Quarterly by a Chinese

The impact of a journal in our profession hinges not only on the strength of evaluation by those reading the journal, but also by the number of political scientists who are likely to have regular access to its published findings.

politics expert or in the Journal of Latin American Studies by a Latin Americanist may carry great weight. On the other hand, some in our profession will want to make assessments based on both the evaluation and profession-wide visibility of a journal. In these cases, a publication in the American Political Science
Review, World Politics, Comparative Politics, Journal of Conflict Resolution, or Daedalus may be perceived as reaching a wider audience and, therefore, contributing more broadly to the visibility and/or national reputation of the individual or department in question. Of course, the selection of evaluative criteria for making these types of decisions is a value judgment. But having two sets of journal rankings may assist those who have made their value judgments in making relevant evaluative decisions.

\section{References}

Giles, Micheal, Francie Mizell, and David Patterson. 1989. "Political Scientists' Journal Evaluations Revisited." PS: Political Science and Politics 22: 613-17. Giles, Micheal and Gerald Wright. 1975. "Political Scientists' Evaluations of SixtyThree Journals." PS: Political Science and Politics 8: 254-57.

\section{About the Author \\ James C. Garand is associate professor of political science at Louisiana State University. He has published in the American Political Science Review, Journal of Politics, Western Political Quarterly, Legislative Studies Quar- terly, and the American Politics Quarterly.}

\title{
Interviewing Political Elites
}

\author{
Robert L. Peabody, Johns Hopkins University \\ Susan Webb Hammond, American University \\ Jean Torcom, California State University, Sacramento \\ Lynne P. Brown, New York University \\ Carolyn Thompson, Johns Hopkins University \\ Robin Kolodny, Johns Hopkins University
}

Interviewing political elites-Presidents and Cabinet members;

Senators and Representatives;

Supreme Court Justices; White House, executive branch and congressional staff; political party and congressional campaign committee officials; lobbyists and media personnel-is both an art and a craft. All of these people, even those who have stepped down from their official duties, are busy and value their time. Hence, those who seek interviews with them must prepare carefully and use interviewing time wisely. The same admonition applies to those who choose to interview the state and local counterparts of these national elites. Since so many political scientists conduct interviews with political elites-as preparation for a dissertation, an article, or a bookthe authors thought it would be helpful to share with our colleagues the techniques and strategies that have worked well for us in a wide variety of field settings and interview situations.

Our argument is simply this: Techniques of interviewing political elites can be taught and disseminated; the art of interviewing respondents and informants can best be learned from experience. This article provides information about (1) when interviews are an appropriate research strategy; (2) ways of drafting a focused, semi-structured interview schedule; (3) means of obtaining 
access to political elites; (4) techniques for beginning an interview, putting respondents at ease and ending an interview; (5) how best to record the information, including whether or not to use a tape recorder; and (6) how to make the most appropriate use of interview data in written material, such as an article or book. We are dependent, as are all who conduct elite interviews, on the contributions to this subject of such seminal social scientists as Robert Merton (1956), Lewis A. Dexter (1970), Richard F. Fenno, Jr. (1978) and Aaron Wildavsky (1989).

The mechanics can be taught; but ultimately, interviewing, like sailing, cooking, or playing the piano, is a form of artistic achievement. You can do it well, or you can just get by. Self-awareness and appreciation of the transactional nature of elite interviewing (Dexter, 1970) are crucial to success.

What qualifies us to write about interviewing political elites? For 30 years the senior author has based most of his research and writing on interviews, beginning with a study of Organizational Authority (1964) and continuing with research on House and Senate party leadership: Leadership in Congress (1976). All of the authors have conducted or are in the process of completing research based in large part on the use of semistructured, focused interviews with political elites, including members of Congress and their staffs

(Hammond); Republican senators, Senate staff and lobbyists (Torcom); House leaders and staff (Brown); Cabinet, White House, and executive branch officials and health interest group representatives (Thompson); and political party and campaign committee officials (Kolodny). ${ }^{1}$

Before turning to a discussion of the craft of interviewing, a brief distinction among three types of interviews is worth making: (1) the fully structured, or survey research interviews; (2) the semi-structured, focused interview (our principal concern here); and (3) the relatively unstructured or journalistic type. "A structured interview is characterized by a carefully designed interview schedule, a set of questions that are always asked in a particular order, and often, a high proportion of questions that have a fixed or closed response. ... A semi-structured interview allows more opportunity for probing and gives the respondent considerable freedom to expand on a given question" (Huitt and Peabody, 1969, pp. 28-29). The unstructured interview, typically used by journalists, but occasionally by political scientists, is time specific and contextual: "What are the chances of this bill being reported out of committee next week?"

(1) When are interviews an appropriate research strategy? Almost

\section{Participation in the American Political Science Association's Congres- sional Fellowship Program has provided political scientists and journalists with exceptional oppor- tunity to conduct research involving the observation and interviewing of political elites.}

always. With the important exceptions of library- or computer-based research by political theorists, political historians, formal choice theorists, or election analysts, almost all other fields of political science research lend themselves to field investigation and the use of focused interviews. It may be more difficult for international relations researchers to tap into the expertise of others, but studies in comparative politics increasingly involve field research. Studies of state and local government, public administration, and national political institutions offer great potential for the use of interviews, often accompanied by opportunities for participant-observation. For nearly four decades, for example, participation in the American Political Science Association's Congressional Fellowship Program has provided political scientists and journalists with exceptional opportunity to conduct research involving the observation and interviewing of political elites.

(2) Drafting and using a focused interview schedule. Once you have decided to do field research and conclude that there are people out there who know more about your subject than you do, the next step is to design an interview schedule. Your research focus, working hypotheses, and need for systematic data will guide you in the number and kinds of questions you will want to ask. Here are some cardinal rules for developing and using a semi-structured interview schedule:

a) The number of questions that can be asked is directly related to the amount of time you can expect with the respondent. This may range from as few as ten minutes with a top national leader to a more typical half-hour to an hour. (In requesting time with a U.S. Representative or a Senator, it is usually better to ask for 20 minutes, with the hope that the member's schedule or interest in your work will lead to greater time). The first few questions you ask are the most critical for establishing rapport. They should be fairly simple and direct, but also indicate that you have considerable knowledge of and insight into the issues or personalities under discussion.

b) Run pilot interviews with your friends and colleagues. Test the time it takes to administer the interview, and then adjust accordingly. Move the questions around and consider different wording.

c) Don't ask questions to which you should know the answers (e.g., "When were you first elected to Congress? On what committees do you serve?") Do your homework before the interview and go into the meeting prepared with as much background information as possible.

d) Keep the questions neutral. Given the respondent the opportunity to provide relevant information without cues other than your questions. Ask: "What do you consider to be the most important bills handled by your 
committee this session? Why?" Do not ask: "Colleagues have indicated that H.R. 510 and H.R. 1154 were the most important pieces of legislation handled during the last session. Do you agree?" Asking the question the first way is apt to yield much richer information. You may get unexpected answers, you may discover an intra-party conflict, or factors perhaps unanticipated when you designed your research.

e) Start with the simple and factual, and then move to the more interpretive or judgmental questions. The latter may, of course, be what you really want to know. But you won't get to the rich data you want if you start with those questions before you have established rapport.

f) Keep the interview schedule short, initially about eight to ten questions, but be prepared to expand. The interview schedule should be designed so that it can be administered in 20-30 minutes if necessary. This tight time-frame enhances your ability to get to see respondents, and also assures that you will get the data you really need if your respondent is busy and can only give you a limited amount of time.

However, also make the interview schedule expandable; some half hour interviews may last up to one or two hours. These are often the most productive sessions and may provide the most unexpected and valuable information. And remember, some of the keenest insights may be obtained after the interview is officially over, and the respondent has relaxed. Be prepared to stay!

g) Know your interview schedule thoroughly-know it so well that you can revise it while administering it. If a respondent answers Qn. 6, while responding to Qn. 2-you then ask Qn. 7, if it follows logically. Later, you can get back to Qns. 3, 4, and 5. Careful work developing the interview questions will pay off, even if the respondent doesn't follow your carefully pre-designed interview plan.

(3) Means of obtaining access. Once you have decided to use interviews in your research, how do you decide whom you want to interview? This is not as easy a question as it sounds. Should you start at the top or begin with staff interviews and work your way up? What is the best way of making initial contact? We have found it strategic to initiate a request for an interview with a letter explaining the project, usually on departmental stationery. This should be followed by a telephone call to establish a specific time and place. Gaining access to elites requires both persistence and patience, as well as a strong ego. Don't be intimidated by "gate keepers": they are, after all,

\section{The best of quotations are} no substitute for thinking and formulating themes.

only doing their job. If, after several call backs, you still haven't succeeded, the next step, if you are in town, is a personal visit. Don't take rejections personally.

Don't overlook the possibilities of interviewing former members of Congress, agency heads, or lobbyists who have sought another calling. Such sources frequently have more time and most have retained their "institutional memory." Often, a strong source is one who left governmental service or party leadership for academia and is comfortable with the practice of scholarly research.

(4) Ways of beginning an interview, putting respondents at ease, and ending an interview. While you are waiting for an interview to begin, do not hesitate to look around and observe what mementoes are in the office. Sometimes, a comment about a map of the district, or a photograph on the wall, is a good "ice breaker," a way to get the principal to talk about himself or herself. But do not forget the purpose of the meeting, and at the first appropriate moment, take the time to explain your project and launch your questions. Often, a personal career question, one that demonstrates that you have done your homework but need further information, is a good way to begin.

Terminating an interview embodies many of the same principles as beginning the interview. Thank the respondent for his or her time and consideration. If the interview has gone well, you should ask the respondent if he or she can recommend others who would be particularly good contacts. On occasion, you may encounter a hostile subject, or one who is just too harried to answer your questions. Be professional and polite; thank your source and leave. And don't take the experience with you to the next interview.

One last recommendation: make a point of stopping to thank the appointments secretary for any assistance given you. A follow-up letter of appreciation, perhaps personalized to recall some aspect of the interview, is recommended. Not only is such a gesture a common courtesy, it helps to make the respondent more receptive to possible future interviewers, including yourself.

(5) How best to record the interview. A primary dilemma confronting someone engaged in field research is how best to take down the information from an interview. Generally, researchers adopt one of three strategies (1) rely on one's memory during the meeting and wait to record the information until the interview is over; (2) try to take highlights or more thorough notes while the interview is in progress; and (3) ask permission to use a tape recorder, along with the assurance that the respondent will not be identified or quoted without permission. Selections among these routes will vary from project to project, and even from one researcher to another. Each method has its advantages; each its drawbacks.

Richard F. Fenno, Jr., makes a strong case for the first method. He believes that he is better able to establish rapport, and maintain eye contact, by seldom taking notes and not utilizing a tape recorder during his participant-observation and interviewing (Fenno, 1978, Appendix). Other scholars have found it comfortable to take notes, after asking permission, and believe the ability to capture key words and phrases is more satisfactory. 
The advantage of the tape recorded interview is that it yields a complete and accurate transcript of what was said. This is of benefit when you want to use quotations in your text, whether attributed or not. Tape recording has other points in its favor: it permits the interviewer to maintain eye contact and a feeling of informal conversation while the interview is progressing. If the interviewer is inexperienced, a tape recorder can relieve any nervousness about taking notes or remembering everything that was said for later transcription. Tape recorders today are so small that they generally are not an obtrusive presence.

The major drawback of the tape recorder, however, is a considerable one. Some political elites may be reluctant to talk "for the record," even if anonymity is assured. Generally speaking, the more sensitive and personalized the information, the less appropriate is the use of a tape recorder. Since the events of the last twenty years, including Watergate, FBI sting operations, and investigations of corruption in government, politicians are more reluctant than ever to permit the use of tape recorders when discussing sensitive materials. Even if the respondent permits the use of a recorder, he or she may be so inhibited by its presence that the interview loses its spontaneity and answers may be guarded or hedged. A further limitation is the time and cost it takes to transcribe the interview.

In those interviewing situations where tape recording seems inappropriate, but note taking does not-the situation in many elite interviewing situations-scholars have developed various tactics to facilitate their objectives. One is to have a relatively brief set of questions-eight or tenand to ask them almost always in the same order. By jotting down key words and phrases of the respondent's answers you can jog the memory, permitting the rest of what was said to come back later. This strategy requires that you repair immediately to a quiet place after the interview to write down as much as you can recall as soon as possible. It is a good idea not only to go over your notes immediately, filling in gaps and phrases, but also to type them up or put them in a computer within the next day. Notes can grow cold very quickly.

(6) How to make the most appropriate use of interview material in your writing. The real purpose of conducting research is not for the thrill of participant-observation, although that can be most exciting, or even the satisfaction of conducting a successful interview. Ultimately, the research comes to naught if you are not able to transform it into a written, publishable product. Accumulation of knowledge is mostly what the discipline is all about, whether you are setting forth a new theoretical framework or "merely" filling in a dominant paradigm (Kuhn, 1962).

What can be said about using interview data in written reports, be it a dissertation, article, or book? First, the best of quotations are no substitute for thinking and formulating themes. The cart (interviews) must come after the horse (your leading propositions). Second, you must use quotations, however apt, selectively. One of the more devastating critiques is: "The article was nothing more than a string of quotes." You must first formulate your hypotheses, and then analyze the interviews systematically. Some scholars now code interview data for computer analysis. Conversely, you should also be alert as you read through your interviews for new ideas and insights - the serendipity factor. A principal purpose in conducting interviews in the first place is to gain a perspective on a subject that was not possible from afar.

\section{Conclusions}

One of the most potent, high-yield ways of studying political elites is to interview them. Not only are you able to watch performance at firsthand-a form of participant observation-but you are able to elicit perceptions and record data about an unfolding and intriguing research topic of your own choice. The successful interviewer, with skills honed over time, is one who develops a keen awareness of his or her own reactions and those of the respondent. Hence, as Dexter (1970) points out, the inevitable transactional nature of the process: inter- viewer and respondent both influence the nature of the interview itself. The personality of the interviewer and his or her commitment to the task become critical to the outcome. Dean Hammer and Aaron Wildavsky $(1989$, p. 58) capture well the qualities called for:

The first requirement for those who wish to accept this daunting task without self-destruction is courage. The second is resilience, the capacity to bounce back, to learn from error how to do better, to be buffered from adversity-rejections, hostility, missed opportunities-and go at it again. The third and final requirement is selfmanagement, the use of personal experience to develop a personal style of interviewing that will withstand the blows and bridge the gaps and inconsistencies. . . .

But interviewing elites is not all work. It can also be the source of great challenge, inspiration, and not a little joy. Our final word of advice: Prepare yourself as best you can and plunge in. As Richard Fenno has observed: "We need political scientists to go take a first-hand look at our politicians and report back to us. ... For only we can persist in attaching observation to theory" (Fenno, 1986, p. 14).

\section{Notes}

1. Robert L. Peabody, Organizational Authority (New York: Atherton Press, 1964); Peabody, Leadership in Congress: Stability, Succession and Change (Boston: Little, Brown, 1976); Peabody, "Senate Party Leadership: From the 1950s to the 1980s," in Understanding Congressional Leadership, Frank

Mackamen, ed. (Washington: Congressional Quarterly Press, 1981).

Harrison, W. Fox, Jr., and Susan Webb Hammond, Congressional Staffs: The Invisible Force in American Law-Making (New York: The Free Press, 1977); Hammond, "Congressional Caucuses in the Policy Process," in Congress Reconsidered, Lawrence Dodd and Bruce Oppenheimer, eds. (Washington:

Congressional Quarterly Press, 1989).

Jean Torcom, "Minority Leadership in the Senate: The Role and Style of Everett

Dirksen," in Sven Groennings and Jonathan

Hawley, eds., To Be A Congressman

(Washington: Acropolis Books, 1973).

Lynne P. Brown and Robert L. Peabody, "Dilemmas of Leadership: Majority Whips in the U.S. House of Representatives, 1963-

1982," in Congress \& the Presidency (Autumn, 1984) 11: 179-196.

Carolyn R. Thompson, "The Political Evolution of the Medicare Catastrophic Health 
Care Act of 1988"' (Ph.D., The Johns Hopkins University, 1990).

Robin Kolodny, "The Role of the Congressional Campaign Committee in Party Develop" ment and Leadership Selection in Congress" (Ph.D., The Johns Hopkins University, in progress).

\section{References \\ Bonafede, Dom. 1983. Interviewing Presiden- tial Aides: A Journalist's Perspective. In George C. Edwards III and Stephen J. Wayne, eds., Studying the Presidency. Knoxville: University of Tennessee Press. Dexter, Lewis A. 1970. Elite and Specialized}

Interviewing. Evanston: Northwestern University Press.

Fenno, Richard F., Jr. 1978. Home Style: House Members in their Districts. Boston: Little, Brown.

Fenno, Richard F., Jr. 1986. Observation, Context and Sequence in the Study of Politics. American Political Science Review 80: 3-15.

Gorden, Raymond L. 1980. Interviewing: Stratgegy, Technique, and Tactics. Homewood, IL: Dorsey Press.

Hammer, Dean and Aaron Wildavsky. 1989 The Open-Ended, Semi-Structured Interview: An (Almost) Operational Guide. In Aaron Wildavsky Craftways: On the
Organization of Scholarly Work. New Brunswick: Transaction Publishers.

Huitt, Ralph K. and Robert L. Peabody. 1969. Congress: Two Decades of Analysis. New York: Harper and Row.

Kuhn, Thomas. 1962. The Structure of Scientific Revolutions. Chicago: Chicago University Press.

Merton, Robert K. 1956. The Focused Interview: A Manual of Problems and Procedures. New York: The Free Press.

Pica, Joseph A. 1983. Interviewing Presidential Aides: A Political Scientist's Perspective. In George C. Edwards, III and Stephen J. Wayne, eds. Studying the Presidency. Knoxville: University of Tennessee Press.

\title{
The National Endowment for the Humanities and Political Science After 25 Years
}

\author{
Ellis Sandoz, Louisiana State University
}

When it started out in 1965 , the National Endowment for the Humanities (NEH) was viewed with high expectations by the political science fraternity in the United States. Those expectations have been amply fulfilled over the past quarter of a century. NEH has become today an important source of external funding for political scientists with a wide range of interests and for political science-related programs, teaching and research. Over $\$ 14$ million were devoted to such projects during the 1980s when a crescendo came with the Bicentennial of the Constitution.

\section{What were the initial expectations?}

In calling for establishment of NEH in 1964, the APSA mustered five distinguished members to draft a position paper: Herbert Deane of Columbia, John H. Hallowell of Duke, H. Malcolm Macdonald of Texas, Frederick M. Watkins of Yale, and Sheldon Wolin of California-Berkeley_political theorists all. What they saw as the chief desideratum in the wake of Sputnik, the gearing up for the space race in all fields of science and technology, and the surge of sciency behavioralism in political science is not surprising. As they wrote in controlled understatement:

Some areas of study in political science and some methods of pursuing that study are more generously endowed than others. It is in the interest of balanced support that we urge the establishment of a National Humanities Foundation. It is now somewhat easier for political scientists who are concerned with the use of quantitative methods to secure financial support for their research activities than it is for those among us whose interest in politics is more philosophically and normatively oriented. This is not to disparage the work of those who are endeavoring to make the study of politics more scientific; rather, it is a plea for the support of those areas of political research and training which are most directly related to the concerns shared by the humanities (Report of the Commission on Humanities, 201).

The urgent needs of political scientists that might be met by establishing NEH were identified as including: fellowships for able graduate students preparing to teach political science, with stress on support for travel to do research and attention to foreign language training; post-doctoral support; improving the teaching of government in secondary schools as a matter of citizenship training; programs to prepare textbooks and related instructional materials, especially as these bear on the nature and rise of communism because many states were mandating instruction in that subject; and money for research, giving priority to the field of political philosophy, since such roots of our own tradition as the "rule of law" as well as the bewildering array of "contemporary political ideologies" fall within the purview of theory.

"Research in political philosophy is the least well-endowed field of research in political science, but the questions to which it seeks answers are of ultimate concern," our authors argued (Report of the Commission on Humanities, 205). But such other areas as the study of public law, comparative government, public administration, and international relations were identified as intimately connected with the concerns of the humanities as well.

"The criterion for support of such projects by [the NEH] might be whether the research project was normatively oriented," the APSA spokesmen suggested. In the heydey of the aspiration to value-free 